\title{
The Implementation of Formative Assessment in EFL Writing: A Case Study at a Secondary School in Indonesia
}

\author{
Annisa Nurhayati \\ Universitas Sebelas Maret, Indonesia \\ Email: nurhayatiannisa9@gmail.com
}

\begin{abstract}
The formative assessment offers more informative aspects for the improvement in teaching and learning activity, unlike the summative assessment that teachers commonly apply. Therefore, the essence of learning is accomplished. Furthermore, the teachers can adjust the teaching to suit the students' needs through formative assessment. However, such research about formative assessment in English Foreign Language context is limited. This study intended to see the practice of formative assessment in the English Foreign Language writing class of the secondary school students and its impact on the teaching and learning activity. Thirty students and an English teacher participated in this research. In undergoing this case study, the researcher gathered the data from the questionnaire and interview, then analyze the data using inductive procedure analysis. The study revealed that students obtained more opportunity to share ideas with their peers. Therefore, it makes students more active in learning. Formative assessment also helps the students to improve writing in several aspects such as the grammatical aspect and the language use. Besides, students built up a positive attitude to writing and formative assessment as they can reflect from the discussion and feedback. This research will benefit teachers regarding conduct formative assessment in EFL writing and for other researchers to carry out the same research topic.
\end{abstract}

Keywords: Case Study, EFL Writing, Formative Assessment, Secondary Students, Summative Assessment.

\section{INTRODUCTION}

Writing in English as Foreign Language (EFL) is crucial to get proper assessment so that students can reflect and learn better through the assessment result. In reality, normally, teachers assess students' writing by giving a mark or grade with some correction on it. This kind of assessment, namely, summative assessment, evaluates students' learning in the form of number as its result. As Bennett(2011) mentioned that summative assessment was conducted to assess learners' achievement as a course finish. It mainly focuses on the learning product and not the process. As a result, the students are only interested in the mark without taking the correction seriously for learning. Hence, this kind of assessment has a minimum 
role in encouraging better learning and teaching writing. However, formative assessment is more promising in assessing as well as accommodating learning in English as Foreign Language (EFL) writing. Formative assessment completes the summative assessment since it gives comprehensive information about students' writing.

Nowadays, formative assessment is progressively acknowledged as essential for language evaluation (Lee \& Coniam, 2013). This is because the language learners and teachers may take the information collected from formative assessment to make a judgment of the activity and strategy for the learning. Therefore, formative assessment is believed to be advantageous for students' learning. Teachers can identify how far or how good the students learn and to observe the progress. Meanwhile, English as a Foreign Language (EFL) writing needs more innovative and meaningful assessment for students to get real improvement. Thus the implementation of formative assessment in the EFL writing context is essential. A fundamental claim of formative assessment, as well as feedback in higher institutions, stated that teachers should employ it to help students to be independent learners (Nicol \& MacFarlane-Dick, 2006).

Several studies regarding formative assessment are conducted under the context of primary, secondary and even university context. The previous study carried out in the university context (Naghdipour, 2016) focuses on the formative assessment for undergraduate students in the Iranian EFL context majoring in English. Meanwhile, the other studies (Lee, 2011; Mak \& Lee, 2014) focus on the case study of formative assessment in EFL writing in a secondary school in Hong Kong. Another study about the formative assessment of writing in EFL context focused on the teacher's and student's perspective regarding formative assessment (Burner, 2015). Applied in a different context, those researches showed significant impacts of formative assessment for English as Foreign Language (EFL) writing and its assessment.

The previous researches mainly focused on the teachers' attempts and the challenges in the implementation of formative assessment and the impact of formative assessment on the students' writing performance. Therefore, to fill the gap, this research concerns the practice of formative assessment in English as Foreign Language (EFL) writing for the secondary students in Indonesia. Specifically, this research observes how far formative assessment gives the best impact for the secondary students in English as a Foreign Language (EFL) writing teaching and learning activity, as well as the influence of formative assessment towards the students' attitude and beliefs responding to the EFL writing and formative assessment. Those aspects are essential to discuss to get more insight into the formative assessment from the students' point of view.

This study intended to describe the impact of formative assessment for the teaching and learning of the activity, and the assessment practice in writing. Besides, the study aims to find out the impact of formative assessment on the students' beliefs and attitudes related to writing and the formative assessment in English Foreign Language writing class. This study is hoped to be beneficial for teachers in obtaining more information about assessment in writing to seek improvement in EFL writing evaluation. Besides, it is advantageous for other researchers as literature for future research, particularly in formative assessment and in the context of EFL writing.

\section{Formative Assessment}

Black \& Wiliam (1998) mentioned that formative assessment is all the actions conducted by teachers and their students to evaluate themselves-that give the light as a response to adjust the classroom activity. It indicates that formative assessment is useful to 
conduct for the teacher who is seeking enhancement of the class activity. The teacher is not the only actor who actively involved in the assessment, but also the students. Meanwhile, Sadler as cited in (Nicol \& MacFarlane-Dick, 2006) stated that formative assessment means the evaluation that its purpose is to get feedback to develop and enhance students' learning. Formative assessment, therefore, is an assessment that offers information as meaningful feedback for the development of learning.

For this reason, feedback is one of the essential aspects that exist in formative assessment. Concurrently, whichever means may be employed (Bennett, 2011). The method of giving feedback is varied as long as it fulfills the purpose and the necessity. According to Black \& Wiliam (2009) there are several strategies regarding formative assessment as to its conception:

a) Clarifying and sharing learning intentions and criteria for success; b) Engineering effective classroom discussion and other learning tasks that elicit evidence of student understanding; c) Providing feedback that moves learners forward; d) Activating students as instructional resources for one another, and e) Activating students as the owners of their learning.

Bennett(2011) mentioned that the strategies are associated with cognitivescientific theory, particularly concerning social interaction during learning. This kind of development-oriented assessment also describes as the concept of proximal development (Vygotsky, 1979) as cited in (Naghdipour, 2016). Sharing expectations, questioning, feedback, self-assessment, and peer-assessment are purposed to assist students in reflecting and then improving their work. Those strategies are the essential ones when conducting a formative assessment. The strategies help the essence of evaluation achieved.

Also, the practice of formative assessment in writing is in line with the strategies-based instruction (Graham \& Perin, 2007), which provides precise teaching and learning strategies and learners' active participation during learning. An essential strategy stimulated by formative assessment is formative feedback which provides students more meaningful and realistic activities that can encourage independent learning (Mcdowell et al., 2011). Formative feedback is an important aspect of formative assessment to help students assess and improve their writing as well as enlighten teachers of future instruction in teaching.

\section{EFL Writing Formative Assessment}

Assessment in writing usually is in the form of summative assessment where the teachers focus on the students' writing product and ended up in the form of a score with no follow-up feedback for better writing. A case in Iran, writing assessment mainly focuses on students' product with a lack of feedback related to students' work (Birjandi \& Tamjid, 2011; Naghdipour, 2016). Meanwhile, in Indonesia, teachers generally conduct a traditional assessment that focuses on grading students' accomplishment; thus, students cannot obtain any reflection from their work (Ratminingsih et al., 2017). The score seems to be the final result in writing. In other words, students' involvement in writing assessment is minimal. The students' role in the process of assessment is not concerned well.

Lee (2007) mentioned that the teacher evaluated the students' script of writing through feedback that the aim tends to be summative. Students have such a paradigm about the assessment that since the test is over, it means that the learning is finished. There is no continuous action, such as feedback towards the assessment result. Lee (2011) stated that regardless of the teacher's attempt to do 
complete rectification to students' inaccuracy, it is still unsure if it supports learning. Students mostly care only to the scores and do not concern teachers' feedback as an opportunity to obtain improvement. Therefore, it can be said that such assessment practice does not give a greater impact on teaching and learning activity.

Meanwhile writing in the EFL context can be very challenging. This is because there are many aspects such as vocabulary, grammar and cohesion are included in writing. Seeing this fact, students need real and more comprehensive assessments for their learning. Birjandi \& Tamjid(2011) investigated some kinds of assessment strategies and discovered that self and peer-assessment give a major effect on students' writing and support self-regulated learning. It implies that the teacher should take into account self-and peer-assessment to the evaluation in EFL writing. Besides, teachers provide feedback for students regarding which one is correct or incorrect, the strong point as well as the weak point, so that students may use it as an improvement (Nicol \& MacFarlaneDick, 2006). Those principles point out that formative assessment is very potential to assess students' in EFL writing.

\section{METHOD}

The design of the research is a case study. Yin (2018) stated that a case study is a method to examine a real-world phenomenon thoroughly. In this case, the research attempted to explore the practice of formative assessment in EFL writing regarding the impact on teaching and learning activity as well as the students' beliefs towards the practice of formative assessment in EFL writing.

The researcher conducted the study in a high school where the English teacher applied formative assessment in the EFL writing class. The senior high school students are taught about the genre in the writing class. Therefore, a survey was done to several private high schools in Yogyakarta, and it's found that a teacher applied formative assessment to assess the students' writing. As the researcher chose a private school, the researcher decided the class as the sample based on the English teacher's suggestion.

The participants in this research are thirty senior high school students at the age of 15 to 16 years old and an English teacher in the same school as a private high school in Yogyakarta, Indonesia. The students were in the second year of high school. The students were taught about genres such as procedure text, report text, and analytical exposition text in English writing class. They were taught about the text structure, linguistic features of the text such as the tenses, and the organization of the text. As Indonesian speakers, the students have diverse abilities in English writing.

The researcher conducted the study at the end of the second semester as the English teacher conducted a formative assessment in EFL writing. This assessment contains self-and peer-assessment and small conference or discussion. The feedback from the peer and the teacher was given during the assessment. The formative feedback, as the common formative assessment aspect, was offered at both individual and group level (Black \& Wiliam, 1998). In this study, the teacher employed peerfeedback and teacher-feedback to the students besides a discussion at the end of the assessment.

There are two primary sources of data collection used in this study. They are questionnaires and interviews. The researcher distributed the questionnaire to all the students and interviewed with several students who volunteer to be interviewed. The researcher also interviewed the English teacher who applied the formative assessment and as one of the participants in this research. The questionnaire and the interview were done at the end of the semester or when the formative assessment was finished to implement. As the data were collected, the researcher analyzed the data and 
presented the result following the research question.

The data gathered from the questionnaire was aimed to discover the students' beliefs and attitudes about writing and formative assessment. And the data from the interview will describe the impact of formative assessment on teaching and learning activity in EFL writing from the students' as well as the teacher's perceptions. The statements of the questionnaire were the adaptation from Lee (2011) and Naghdipour (2016). The researcher combined it and suited it with the indicators to answer the research questions. The questionnaires are translated into Bahasa to make students understand the questionnaire better.

In analyzing the data obtained from the questionnaires, the researcher analyzed it in three stages. Those stages are data reduction, data display, and conclusion (Miles et al., 2014). First, the researcher employed data reduction. The researcher selected and identified the theme of the questionnaires is associated with the categories. Second, the data were displayed in the form of a table which later analyzed and drawn the conclusion.

The researcher analyzed the students' and teacher's statements and responses toward the interview using an inductive procedure analysis (Thomas, 2006). The researcher read the interview result to classify the themes and categories. The idea of the interview question and the strategy of formative assessment are the indicators of the categories. Thus the concluded quotations were accomplished.

\section{RESULTS AND DISCUSSION}

\section{Results}

Students' attitude and beliefs about writing and formative assessment

The students' attitudes and beliefs related to writing and assessment are essential to concern as one of the objectives of the research. Table 1 presents information about the questionnaire result related to the influence of formative assessment on students' attitudes and beliefs. There are several main points of result that the researcher can analyze.

The first category is about students' beliefs towards writing. Generally, the students' interest in writing is good enough. The item 1 shows that half of the students had a high interest in writing, with the details of 11 students agree that they like writing in English and five students strongly agree with the statement saying that they like writing in English. Item 2 indicates that the students believe that the writing attempt will create excellent writing. However, at item 3, less than half of the students have high self-esteem in writing. There are 17 students who were neutral, three students disagree, and four students strongly disagree with the statement of item 3. It shows that the students have low confidence in writing. Yet, they believe that an attempt will create a good writing result.

Moreover, in items 3 and 4, the students consider that they know their strategy to solve the problem in writing and the way to improve it. More than a half, which is 25 to 26 students, agrees that they know the way to develop writing. This result explains that the majority of the students have a positive belief regarding writing and writing strategies in English as a foreign language.

The second category is about students' attitudes and beliefs related to assessment. This category was described through item 6 to item 8. Generally, at least 24 students agree to significantly agree that the purpose of assessment is for the sake of improvement to students' writing and to facilitate as well as develop the teaching of writing. Although, there are three to six students had a negative belief about the purpose of assessment.

The third category concerns the students' beliefs regarding writing the assessment. Item 9 implies that a detailed assessment of students' 
writing is crucial. Even though the item 10 reveals if the score is still useful for students, but students consider that teacher's response to the written error and wide criteria to assess writing are necessary.

The fourth category concerns written comments and feedback. The Item of 15 and 16 shows that most of the students believed that the teacher should give written comment. There are 20 students agree that written comment is necessary to assess students' writing. However, the students were uncertain whether their strengths should be put into account as a written comment.

The fifth category is related to students' beliefs about the aspect or the strategy of formative assessment for the writing assessment. Those components are discussion or mini-conference and feedback. Item 17 shows that most of the total students believed that the conference to discuss the way to improve writing is beneficial. Meanwhile, item 18 and item 19 indicate that opportunities for selfassessment and peer feedback are considered necessary in writing assessment. Last but not least, item 20 reveals that almost all of the students agree if revision after obtaining feedback is advantageous. These indicate that the students have positive attitudes and beliefs toward

formative

Table 1. Data display of the questionnaire $(\mathrm{N}=30)$

\begin{tabular}{|c|c|c|c|c|c|c|}
\hline \multirow[t]{2}{*}{ No. } & \multirow[t]{2}{*}{ Statement } & \multicolumn{5}{|c|}{$\begin{array}{l}\text { 1=strongly disagree; } \\
5=\text { strongly agree }\end{array}$} \\
\hline & & 1 & 2 & 3 & 4 & 5 \\
\hline 1 & I like writing in English. & 1 & 0 & 13 & 11 & 5 \\
\hline 2 & $\begin{array}{l}\text { When I put the effort into my writing, I can produce a } \\
\text { good piece of work. }\end{array}$ & 2 & 0 & 2 & 12 & 14 \\
\hline 3 & I am good at writing in English. & 4 & 3 & 17 & 5 & 1 \\
\hline 4 & $\begin{array}{l}\text { I am ready to take responsibility to overcome my } \\
\text { difficulties in writing. }\end{array}$ & 1 & 1 & 3 & 15 & 10 \\
\hline 5 & I know what to do to improve my writing. & 0 & 1 & 2 & 23 & 3 \\
\hline 6 & $\begin{array}{l}\text { The purpose of the assessment is to find out how well } \\
\text { or how badly I perform. }\end{array}$ & 0 & 0 & 1 & 17 & 12 \\
\hline 7 & $\begin{array}{l}\text { The purpose of assessment is to help me improve my } \\
\text { writing. }\end{array}$ & 1 & 0 & 2 & 13 & 14 \\
\hline 8 & $\begin{array}{l}\text { The purpose of assessment is to help my teacher } \\
\text { improve her teaching }\end{array}$ & 0 & 1 & 5 & 11 & 13 \\
\hline 9 & $\begin{array}{l}\text { I think my teacher should assess every piece of } \\
\text { writing I do }\end{array}$ & 1 & 0 & 11 & 14 & 4 \\
\hline 10 & $\begin{array}{l}\text { I think scores are useful in helping me improve my } \\
\text { writing. }\end{array}$ & 1 & 1 & 10 & 12 & 6 \\
\hline 11 & $\begin{array}{l}\text { I think my teacher should focus only on grammatical } \\
\text { accuracy when assessing my writing. }\end{array}$ & 2 & 7 & 14 & 4 & 3 \\
\hline 12 & $\begin{array}{l}\text { I think my teacher should respond to the most serious } \\
\text { problems in my writing. }\end{array}$ & 0 & 4 & 15 & 7 & 4 \\
\hline 13 & I think my teacher should respond to all my written & 0 & 3 & 11 & 13 & 4 \\
\hline
\end{tabular}




\begin{tabular}{|c|l|c|c|c|c|c|}
\hline & errors. & & & & & \\
\hline 14 & $\begin{array}{l}\text { I think my teacher should use broad criteria (like } \\
\text { content, language, and organization) to assess my } \\
\text { writing. }\end{array}$ & 0 & 2 & 13 & 10 & 4 \\
\hline 15 & $\begin{array}{l}\text { I think my teacher should provide written comments } \\
\text { on my writing. }\end{array}$ & 0 & 0 & 10 & 15 & 5 \\
\hline 16 & $\begin{array}{l}\text { I think my teacher should comment on my strengths } \\
\text { in writing }\end{array}$ & 0 & 1 & 17 & 9 & 3 \\
\hline 17 & $\begin{array}{l}\text { It is useful to have conferences with my teacher to } \\
\text { discuss how my writing can be improved. }\end{array}$ & 1 & 0 & 3 & 16 & 10 \\
\hline 18 & $\begin{array}{l}\text { It is useful to have opportunities to assess my } \\
\text { classmates' writing. }\end{array}$ & 1 & 2 & 12 & 12 & 3 \\
\hline 19 & $\begin{array}{l}\text { It is useful to have opportunities to assess my own } \\
\text { writing. }\end{array}$ & 0 & 1 & 12 & 14 & 3 \\
\hline 20 & $\begin{array}{l}\text { It is useful to revise my writing after receiving } \\
\text { feedback. }\end{array}$ & 0 & 1 & 0 & 15 & 14 \\
\hline
\end{tabular}

*The number represents the distribution of the students' answers for every Item.

Formative assessment impact toward EFL writing

To find out the impact of formative assessment, the researcher interviewed the teacher and some students. The result of the interview with the students and the teacher provides a clearer explanation about the impact of formative assessment on teaching and learning activity as well as the writing assessment practice. Through the data analysis, it is concluded several themes that formative assessment created several impacts in the context of English as Foreign Language (EFL) writing.

Towards the first Item of the interview, the teacher stated that formative assessment brought a new experience in the practice of assessment in English as Foreign Language (EFL) writing. The following script describes the first impact:

I think the assessment becomes more effective because the students and I actively assess the writing. The students know what they should improve in writing, although it actually takes time.

In response to the second Item of the interview related to the changes in students' learning activity, the teacher explained that formative assessment builds up a better learning activity in EFL writing class. The teacher mentioned that the students actively involved in the assessment. Therefore the students have more opportunities to learn from their own and peer's mistakes which create meaningful learning. This is because self-assessment and peer-feedback were carried out during the evaluation or assessment session.

As I performed this formative assessment, I observed that the students were able to learn more after the evaluation. They realized their mistakes in writing, so they share ideas or answer with their friends. So after the evaluation or the assessment, the students were not stuck in their condition, confuse or having no idea of their mistake, because of the feedback from their friends.

The third response is related to the formative assessment strategies, the discussion or small conference and feedback, toward students' learning activity and the practice of writing assessment. The teacher explained that the discussion encouraged the students to be 
more active in the process of assessment and learning activity. Some students were very confident in expressing their idea, and it helped the students to learn from each other. It is also beneficial for the teacher because the students can learn better by a discussion with their peers.

Yes, I think discussion stimulates the students to be active in learning and its evaluation. They can share their ideas which I believe is very useful for the students to improve their weaknesses in writing.

Meanwhile, on the influence of feedback, the teacher described that it gives a positive impact on the students' learning and assessment practice. The feedback from their peer and the teacher are helpful as the reflection, and things to consider improving in future writing. The following script illustrates the impact:

Yes, I think feedback is good for the students' learning. From the feedback from their friend and the teacher, they will learn things to improve.

Alongside with the teacher's response, the students' response related to formative assessment was quite good. The implementation of formative assessment helps them to get real learning by sharing and actively involved in the writing evaluation.

I think the assessment is better and more distinct from the previous assessment. We not only know our writing's score but also know the things we need to improve. We can help each other with our friends in learning so that we can write better at the next chance.

In related to the feedback as the essential aspect of formative assessment, the students considered it is beneficial because they may find out their writing error such as the grammatical mistake and spelling from their friends. The feedback from their friends makes them quickly realize their mistake and learn from it.
The feedback I experienced before is shorter and not detail. Now I think my friends' feedback helps me to improve my weakness in writing because I am able to know my mistake in the grammar and the wrong words I write. Besides, we also can learn from other's mistakes, so that we may look for the correct answer.

It's almost similar to the friend's feedback (peer-feedback), students believe that the feedback from their teacher is very helpful since it provides detail feedback for the improvement in writing. The teacher's written comment toward students' writing also motivates students to write a better quality of writing.

I think my teacher's feedback in writing is very supportive. Not only feedback about the grammar, but the feedback about the content encourages me to write better.

Another interview question to the students is about whether the discussion, as the formative assessment strategy, is helping to improve students' learning and evaluation in writing. The students' response has a similar idea to the teacher's response. The students believe that discussion is advantageous for them to share knowledge in writing with their friends. By discussion, the students engage directly in the process of the writing assessment. The students' response is as follow:

During the discussion, I can ask and listen to our friends' ideas. I also can tell you about my opinion.

In summary, the analysis of the data from the interview with the teacher and several students reveals that formative assessment created positive impacts on the teaching and learning activity and the assessment practice in English as Foreign Language (EFL) writing. 
The students have more opportunities to share ideas with their classmates and the teacher; therefore, it makes students more active in learning. In addition, since the students actively engage in the assessment, the practice of writing assessment becomes more meaningful to evaluate students' EFL writing than the previous one. The idea of feedback and discussion gives a greater benefit for students to get reflection for future improvement in writing.

\section{Discussion}

This study investigated the practice of formative assessment in English as a Foreign Language (EFL) writing for senior high school students. This study intended to comprehend more about the students' beliefs and attitudes to writing and the formative assessment in English Foreign Language writing class and how formative assessment affects the teaching and learning activity in English as Foreign Language (EFL) writing context. Therefore, there are two points of discussion related to the result.

The first point is about the students' attitude and beliefs. Based on the analysis, it revealed that the students possessed positive attitudes and beliefs towards writing and the formative assessment. It is proved that half of the students have a good interest in writing. The students believe if they try harder to write, their work will be better. After the English teacher implemented a formative assessment, the students are encouraged to solve their problem in writing and know how to improve their lack in writing. This category is in line with the formative assessment strategy (Black \& Wiliam, 1998), saying that one of the formative assessment strategies stimulates the students as the owner of their learning. The students know the writing aspect they need to develop and are keen to make it better.

The result of the questionnaire on some statements also explains that the goal of assessment is to diagnose their performance so that the students can improve their writing.
More than that, the students believe that the idea of assessment is to improve the teaching activity in EFL writing. In addition, students believe that response and more detailed comments towards students' writing are important to do in the assessment. A broad criterion of assessment is also beneficial to be successful in writing. This idea is matched to the assessment strategy on the point of clarifying as well as sharing the learning objective, and success criteria since the teacher's response create a clear learning objective that the students want to achieve.

This study also discovered that selfassessment and peer-feedback as the core components in formative assessment are very helpful for the teacher and students to get a reflection of their teaching and learning. On the last Item of the questionnaire, the students consider that revision should be carried out after getting feedback. This is because, through the reflection, students may do better to gain an improvement in writing. The information regarding students' strength as well as weakness is advantageous for students' writing in the future (Mak \& Lee, 2014). This result, again, is also in line with one of the strategies proposed by (Black \& Wiliam, 1998). Formative assessment provides feedback that encourages the students to have progress. In other words, this assessment creates chances for students to be able to conduct self and peer-feedback as well as comments from the teacher. Those activities are significant factors in developing students' writing because they exchange ideas, reflect and use the information from the feedback to look for progress.

The second point is about formative assessment impacts on the teaching and learning activity in EFL writing context. Among the research conducted about the implementation of formative assessment and assessment in writing (Burner, 2015; Lee, 2011; Mak \& Lee, 2014; Naghdipour, 2016) this study intended to find out the influence of formative assessment on the learning activity and the assessment practice in 
EFL writing. The result shows that formative assessment creates positive impacts on teaching and learning activity as well as the practice of the assessment. The data from the interview describe that the teacher and the students felt the benefit of the formative assessment. The teacher considers that formative assessment creates a meaningful experience in writing an assessment. It also builds up a better learning activity because the students were actively involved during the evaluation. This impact is in line with the formative assessment strategy proposed by Black \& Wiliam (2009) that is activating students as instructional resources for one another. The students learn from each other during the assessment.

The idea of discussion proved that formative assessment encouraged the students to be more active and confidence in expressing their idea in a discussion session. It gives the students chances for the students to share their knowledge for the improvement in writing. Therefore, discussion sessions give a good impact on the students' learning activity. Moreover, the teacher felt that this activity is helpful to generate effective teaching. This result is in line with the formative strategies in engineering effective classroom discussion and other learning tasks that elicit evidence of student understanding. Through this assessment, students also obtained a deeper understanding.

The impact of feedback as one of the important formative assessment strategies is significant towards the learning activity and the assessment practice in EFL writing. The students believe that feedback is constructive to have reflection so that the students can make improvements in writing. Mainly, the students explained that feedback in writing facilitated them to develop the grammatical mistake, spelling, and the writing itself. The peerfeedback and the teacher-feedback support the students to write better quality writing. This result is similar to the idea of a formative assessment strategy that is providing feedback moves learners forward (Black \& Wiliam, 2009). Besides, formative feedback provides students with more meaningful and realistic activities that can encourage independent learning (Mcdowell et al., 2011).

The other result is regarding formative assessment influence the students' beliefs and attitudes about writing and writing assessment. The majority of the students stated that they put a high interest in writing. However, half of the students possessed low self-esteem about their ability in writing. But then, after the implementation of the formative assessment, the students are certain that giving a harder attempt will make a better writing result. Meanwhile, the students' beliefs regarding writing assessment after the implementation of formative assessment were good. The students believed that the purpose of assessment is to look for improvement for their writing and teaching and learning activity in the class. This idea is in line with the idea of (Sadler, 1998) as cited in (Nicol \& MacFarlane-Dick, 2006) stated that formative assessment means the evaluation that its purpose is to get feedback to develop and enhance students' learning.

Additionally, a detailed assessment is crucial. The students thought that the teacher should provide written comment and feedback in relation to students' mistakes, weakness and strength, and the other criteria in writing. The students also consider that self-assessment and peer-assessment are very helpful to evaluate their writing and to learn better in the future. The idea of discussion is also important because students think that they may share knowledge and learn from each other from their friends and teacher.

Among those impacts that formative assessment creates towards the teaching and learning activity, the most crucial impact is for the students themselves and the teacher. The main impact is through those strategies or aspects of formative assessment such as peerfeedback, discussion, and teacher's comment; 
the students become active learners in writing English. The students do not only write and get a score from the teacher but also assess themselves and their classmates. By this assessment, students obtain such reflection in learning. Therefore they may repair their lack and improve their competence in writing so that they get meaningful learning.

\section{CONCLUSION}

As the fact that writing is an essential skill of English that the students should master, the assessment towards writing is also matter. The result shows that formative assessment is critical to conduct as it gives a more significant impact for students to get progress in writing and for the teacher to be able to transform the teaching activity which is suitable to the students' need. It also proved that students believe if the formative assessment is necessary to conduct since it helps the students to develop several writing aspects such as grammar, writing content and language use in writing. Therefore, teachers or schools and institutions should take a formative assessment into account as the assessment in the class and EFL writing specifically. Those findings suggest that applying formative assessment is necessary because the involvement of teachers and students in the assessment can achieve the idea of reflection and improvement in teaching and learning writing. For future study, the more specific aspect of formative assessment such as feedback and discussion which is also beneficial in writing is advantageous to conduct.

\section{REFERENCES}

Bennett, R. E. (2011). Formative assessment : a critical review Formative assessment: a critical review. Assessment in Education: Principles, Policy \& Practice, 18(1), 5-25. https://doi.org/10.1080/0969594X.2010.51 3678
Birjandi, P., \& Tamjid, N. H. (2011). The role of self-, peer and teacher assessment in promoting Iranian EFL learners' writing performance. Assessment \& Evaluation in Higher Education, 37(5), 513-533. https://doi.org/10.1080/02602938.2010.549 204

Black, P., \& Wiliam, D. (2009). Developing the theory of formative assessment. Educational Assessment, Evaluation and Accountability, 21(1), 5-31. https://doi.org/10.1007/s11092-008-9068-5

Black, B. P., \& Wiliam, D. (1998). Inside the Black Box: Raising Standards Through Classroom Assessment. Phi Delta Kappa, $1-13$.

Burner, T. (2015). Formative assessment of writing in English as a foreign language Formative assessment of writing in English as a foreign language. Scandinavian Journal of Educational Research, 1-23. https://doi.org/10.1080/00313831.2015.106 6430

Graham, S., \& Perin, D. (2007). A MetaAnalysis of Writing Instruction for Adolescent Students. Journal of Educational Psychology, 99(3), 445-476. https://doi.org/10.1037/00220663.99.3.445

Lee, I. (2007). Feedback in Hong Kong secondary writing classrooms : Assessment for learning or assessment of learning? Assessing Writing, 12, 180-198. https://doi.org/10.1016/j.asw.2008.02.003

Lee, I. (2011). Formative Assessment in EFL Writing: An Exploratory Case Study Formative Assessment in EFL Writing : An Exploratory Case Study. Changing English: Studies in Culture and Education, $18(1)$ 99-111. 
https://doi.org/10.1080/1358684X.2011.54 3516

Lee, I., \& Coniam, D. (2013). Introducing assessment for learning for EFL writing in an assessment of learning examinationdriven system in Hong Kong. Journal of Second Language Writing, 22(1), 34-50. https://doi.org/10.1016/j.jslw.2012.11.003

Mak, P., \& Lee, I. (2014). Implementing assessment for learning in L2 writing: An activity theory perspective. A system, 47, 73-87.

https://doi.org/10.1016/j.system.2014.09.0 18

Mcdowell, L., Wakelin, D., Montgomery, C., \& King, S. (2011). Does assessment for learning make a difference? The development of a questionnaire to explore the student response. Assessment \& Evaluation in Higher Education, 36(7), 749-765.

https://doi.org/10.1080/02602938.2010.488 792

Miles, M. B., Huberman, A. M., \& Saldana, J. (2014). Qualitative Data Analysis (3rd editio). SAGE Publication.

Naghdipour, B. (2016). Incorporating formative assessment in Iranian EFL writing : a case study. The Curriculum Journal, 1-17. https://doi.org/10.1080/09585176.2016.120 6479

Nicol, D. J., \& MacFarlane-Dick, D. (2006). Formative assessment and selfregulated learning: A model and seven principles of good feedback practice. Studies in Higher Education, 31(2), 199-218. https://doi.org/10.1080/0307507060057209 0

Ratminingsih, N. M., Artini, L. P., \&
Padmadewi, N. N. (2017). Incorporating Self and Peer Assessment in Reflective Teaching Practices. International Journal of Instruction, 10(4), 165-184.

Sadler, D. R. (1998). Formative Assessment: Revisiting the Territory. Assessment in Education, 5(1), 77.

Thomas, D. R. (2006). A General Inductive Approach for Analyzing Qualitative Evaluation Data. American Journal of Evaluation, 27(2), 237-246. https://doi.org/10.1177/1098214005283748

Vygotsky, L. S. (1979). Mind in Society. In The President and Fellows of Harvard College (Second). Harvard College. https://doi.org/10.1525/aa.1979.81.4.02a00 580

Yin, R. K. (2018). Designing Case Studies. In Case Study Research and Applications: Design and Methods. 